\title{
Bilateral acute renal cortical necrosis after a dog bite: case report
}

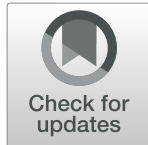

Simon A. Amacher ${ }^{*^{*}}$ (D), Kirstine K. Søgaard ${ }^{2,3}$, Coralie Nkoulou', Raoul Sutter ${ }^{1,4}$, Maja Weisser $^{4,5}$, Sandra S. Zingg ${ }^{5}$, Adrian Egli, ${ }^{2,3}$, Alexa Hollinger ${ }^{1,4+}$ and Martin Siegemund ${ }^{1,4+}$

\begin{abstract}
Background: Capnocytophaga canimorsus is a Gram-negative capnophilic rod and part of dogs/cats' normal oral flora. It can be transmitted by bites, scratches, or even by contact of saliva with injured skin. Asplenic patients and patients with alcohol abuse are at particular risk for fulminant C. canimorsus sepsis. However, also immunocompetent patients can have a severe or even fatal infection. This is the first case of a severe $C$. canimorsus infection in an immunocompromised host complicated by acute renal cortical necrosis with a "reverse rim sign" in contrast-enhanced computed tomography on hospital admission.

Case presentation: We report the case of a 44-year functionally asplenic patient after an allogeneic stem cell transplantation, who presented with septic shock after a minor dog bite injury 4 days prior. Because of abdominal complaints, epigastric pain with local peritonism, and radiological gallbladder wall thickening, an abdominal focus was suspected after the initial work-up. The patient underwent emergent open cholecystectomy, but the clinical suspicion of abdominal infection was not confirmed. Septic shock was further complicated by cardiomyopathy and disseminated intravascular coagulation. As a causative pathogen, C. canimorsus could be isolated. The clinical course was complicated by permanent hemodialysis and extensive acral necrosis requiring amputation of several fingers and both thighs.

Conclusion: We present a severe case of a C. canimorsus infection in a functionally asplenic patient after a minor dog bite. The clinical course was complicated by septic shock, disseminated intravascular coagulation, and the need for multiple amputations. In addition, the rare form of acute renal failure - bilateral acute renal cortical necrosis - was visible as "reverse rim sign" on computed tomography scan. This case is an example of the potential disastrous consequences when omitting pre-emptive antibiotic therapy in wounds inflicted by cats and dogs, particularly in asplenic patients.
\end{abstract}

Keywords: Case report, Reverse rim sign, Capnocytophaga canimorsus, Dog bite, Acute kidney injury

\footnotetext{
* Correspondence: simonadrian.amacher@usb.ch

${ }^{\dagger}$ Alexa Hollinger and Martin Siegemund contributed equally to this work.

${ }^{1}$ Intensive Care Medicine, University Hospital Basel, Basel, Switzerland

Full list of author information is available at the end of the article
}

(c) The Author(s). 2021 Open Access This article is licensed under a Creative Commons Attribution 4.0 International License, which permits use, sharing, adaptation, distribution and reproduction in any medium or format, as long as you give appropriate credit to the original author(s) and the source, provide a link to the Creative Commons licence, and indicate if changes were made. The images or other third party material in this article are included in the article's Creative Commons licence, unless indicated otherwise in a credit line to the material. If material is not included in the article's Creative Commons licence and your intended use is not permitted by statutory regulation or exceeds the permitted use, you will need to obtain permission directly from the copyright holder. To view a copy of this licence, visit http://creativecommons.org/licenses/by/4.0/. The Creative Commons Public Domain Dedication waiver (http://creativecommons.org/publicdomain/zero/1.0/) applies to the data made available in this article, unless otherwise stated in a credit line to the data. 


\section{Background}

Acute kidney injury occurs in up to half of all septic patients $[1,2]$ and carries a significant risk of end-stage kidney disease with the frequent requirement of chronic renal replacement therapy [3].

Acute renal cortical necrosis (ARCN) is an uncommon form of acute kidney injury in states of shock and is the result of direct toxic damage to the glomerular endothelium, as well as microthrombi resulting from sepsis $[4,5]$. In contrast-enhanced computed tomography (CT), the non-perfusion of the renal cortices due to necrosis results in a non-enhancement in contrast to adequately enhancing renal medullae mimicking a retrograde renography [4]. This CT finding is pathognomonic for ARCN and usually results in permanent kidney injury [6].

Capnocytophaga canimorsus is a slow-growing, capnophilic, facultative anaerobic Gram-negative rod. It was first described in 1977 as a dysgonic fermenter 2 (DF2), and in 1989 taxonomically classified as C. canimorsus $[7,8]$. Although C. canimorus is part of the normal oral flora in up to two-thirds of cats and dogs [9], only three serovars $(\mathrm{A}-\mathrm{C})$ cause invasive disease in humans [10]. Its primary mode of transmission to humans is by animal bites, but it can even be transmitted by licks of damaged skin and scratches $[11,12]$. Immunocompromised patients are particularly vulnerable to fulminant $C$. canimorsus sepsis, but also immunocompetent patients may experience severe clinical courses with high morbidity and mortality $[12,13]$. In the sub-group of immunocompromised patients, asplenic patients and patients with alcoholism are particularly vulnerable to $C$. canimorus. In two scoping reviews of published $C$. canimorsus cases, the most frequent clinical entities were sepsis complicated by septic shock, meningitis, multiple organ failure, peripheral gangrene, and DIC with a high case fatality rate of up to $56 \%[12,13]$ Table 1 gives an overview of the variety of possible clinical presentations of C.canimorsus.

\section{Case report}

We recently treated a 44-year-old Caucasian woman who presented to a regional hospital with abdominal complaints and pyrexia for the last $24 \mathrm{~h}$. Past medical history revealed an allogeneic stem cell transplantation 12 years ago due to acute lymphoblastic leukemia, which was in full remission. At the time of infection, the patient had no ongoing immunosuppressive treatment. However, there was evidence of transplantation related functional asplenia by the repetitive detection of HowellJolly bodies in peripheral blood smears and a CTradiographic small, atrophic spleen with a length of 3.8 $\mathrm{cm}$. Four days prior to presentation, the patient was bitten by her dog on the index finger but did not seek medical attendance because there were no signs of infection. Solely, a small sensory deficit of the affected finger was reported. The patient then presented with sudden abdominal cramps, bilious vomiting, epigastric pain, pyrexia up to $40^{\circ} \mathrm{C}$ and shivering.

Upon admission to the regional hospital, the clinical examination revealed a tachycardic, hypotensive, tachypneic, and febrile patient with a tense abdomen and two small skin lesions without any signs of infection on her index finger. An abdominal ultrasound showed a dilated small-bowel with pendular peristalsis, ascites, and gallbladder wall thickening.

Table 1 Selection of clinical presentations of C.canimorsus infections

\begin{tabular}{|c|c|c|c|c|c|}
\hline & Main clinical feature & Age/gender & $\begin{array}{l}\text { Transmitting } \\
\text { animal }\end{array}$ & $\begin{array}{l}\text { Evidence of } \\
\text { immunodeficiency }\end{array}$ & $\begin{array}{l}\text { Survival to hospital } \\
\text { discharge }\end{array}$ \\
\hline Barry et al. [14] & $\begin{array}{l}\text { ruptured mycotic common } \\
\text { iliac aneurysm }\end{array}$ & 86 years/female & dog & no & yes \\
\hline Ashley et al. [15] & aortitis & 80 years/female & dog & no & yes \\
\hline Keshava et al. [16] & septic shock & 42 years/female & dog & no & no \\
\hline Terashima et al. [17] & $\begin{array}{l}\text { hemophagocytic } \\
\text { lymphohistiocytosis }\end{array}$ & 58 years/male & dog & no & yes \\
\hline Bering et al. [18] & purulent meningitis & 67 years/male & cat & $\begin{array}{l}\text { chronic lymphocytic } \\
\text { leukemia }\end{array}$ & yes \\
\hline Klein et al. [19] & septic gonarthritis & 66 years/male & dog & no & yes \\
\hline Squire et al. [20] & infective endocarditis & 76 years/female & dog & no & yes \\
\hline Tani et al. [21] & $\begin{array}{l}\text { disseminated intravascular } \\
\text { coagulation }\end{array}$ & 62 years/female & dog & no & yes \\
\hline Papadaki et al. [22] & endophthalmitis & 60 years/male & dog & no & yes \\
\hline Nelson et al. [23] & vertebral osteomyelitis/discitis & 31 years/male & dog & no & yes \\
\hline Ehrbar et al. [24] & myocardial infarction & 52 years/male & dog & alcoholism & yes \\
\hline
\end{tabular}


For suspected abdominal infection, an empiric antibiotic treatment with piperacillin/tazobactam was started after collecting blood cultures. Hence, the patient was immediately transferred to our tertiary teaching hospital.

Our hospital's initial laboratory work-up revealed signs of infection, coagulopathy, acute kidney injury, and severe lactic acidosis with normal liver/pancreatic parameters (Table 2). The contrast-enhanced CT scan showed a reactive wall enhancement of the gallbladder, ascites, and bilateral ARCN by the "reverse rim sign" (Fig. 1). Due to a high suspicion of cholecystitis causing abdominal sepsis, the patient underwent open cholecystectomy. However, interoperative findings and histological examination did not support this diagnosis.

Postoperatively, the disseminated intravascular coagulation (DIC) worsened, and transfusion of coagulation factors was inevitable, calling for liver packing due to uncontrolled bleeding from the surgical site. Further clinical manifestations of the DIC were profuse bleeding from puncture sites and drainages as well as purpura fulminans. The clinical course was further complicated by a critical hemodynamic instability with profound hypotension and septic cardiomyopathy requiring inotropes. Shortly after admission to intensive care, the laboratory reported identification of rod-shaped bacteria directly from the first peripheral blood smear done in the regional hospital (Fig. 2), suggesting a high pathogen load. Later, blood cultures also revealed Gram-negative rods in Gram staining, which did not grow using standard culture conditions. Together with the clinical information about a dog bite, this raised suspicion for $C$. canimorsus. Bacterial growth was finally achieved on

Table 2 Laboratory results on admission

\begin{tabular}{|c|c|c|}
\hline \multicolumn{3}{|l|}{ Laboratory results on admission } \\
\hline & Result & Reference \\
\hline Leucocyte count $\left(\times 10^{9} / \mathrm{l}\right)$ & 3.87 & $3.50-10.00$ \\
\hline C-reactive protein (mg/l) & 156 & $<10$ \\
\hline Hemoglobin (g/l) & 111 & $120-160$ \\
\hline Thrombocytes $\left(\times 10^{9} /\right)$ & 14 & $150-450$ \\
\hline International Normalized Ratio & 2.2 & $<1.2$ \\
\hline Creatinine $(\mathrm{mmol} / \mathrm{l})$ & 133 & $42-80$ \\
\hline Estimated glomerular filtration rate & 42 & $>90$ \\
\hline \multicolumn{3}{|l|}{$C K D-\left.E P\right|^{a}\left(\mathrm{ml} / \mathrm{min} / 1.73 / \mathrm{m}^{2}\right)$} \\
\hline $\mathrm{pH}^{\mathrm{b}}$ & 7.23 & $7.38-7.42$ \\
\hline Base excess $^{b}$ & -11.2 & $>-5$ \\
\hline Lactate $^{\mathrm{b}}(\mathrm{mmol} / \mathrm{l})$ & 8.7 & $<1.8$ \\
\hline Bicarbonate $^{\mathrm{b}}(\mathrm{mmol} / \mathrm{l})$ & 15.1 & $21-26$ \\
\hline
\end{tabular}

${ }^{a}$ CKD-EPI Chronic Kidney Disease Epidemiology Collaboration [25]

b arterial blood gas

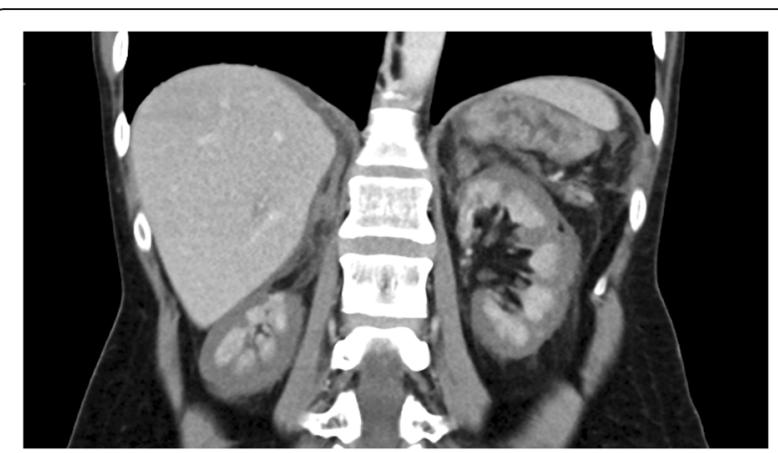

Fig. 1 Contrast-enhanced abdominal CT scan, with a bilateral hypoperfused renal cortex and an adequately perfused renal medulla = "reverse rim sign". This finding is pathognomonic for acute renal cortical necrosis

chocolate agar incubated under micro-aerophilic conditions and identified as $C$. canimorsus by MALDI-TOF mass spectrometry. C. canimorus was sensitive to penicillin $(\mathrm{MIC}=0.004)$ and ceftriaxone $(\mathrm{MIC}=0.023)$. The clinical course was further complicated by permanent hemodialysis and extensive acral necrosis, requiring amputation of several fingers and both thighs. After hemodynamic stabilization and prolonged weaning, the patient could be transferred to the ward after 6 weeks of intensive care and is currently making good progress in rehabilitation.

\section{Discussion and conclusions}

To our knowledge, this is the first published case of a $C$. canimorsus infection complicated by bilateral ARCN with the rare CT-finding of a "reverse rim sign" (Fig. 1) [4-6] C. canimorsus associated disseminated intravascular coagulation may lead to microthrombi in renal glomeruli resulting in permanent kidney failure. $C$. canimorsus is usually susceptible to all beta-lactam antibiotics (including penicillin) and clindamycin. International guidelines suggest amoxicillin-clavulanate as prophylactic therapy after a dog bite [26]. The adjunction of beta-lactamase inhibitors seems reasonable, as beta-lactamases have been isolated in Capnocytophaga spp [27].

Concerning this rare pathogen, there is mainly anecdotal evidence in the form of case reports [7-11] and scoping reviews $[12,13]$ of published cases implicating a significant publication bias. Well-designed prospective research is warranted to gain further knowledge regarding this chameleon-like disease.

In conclusion, immunocompromised patients should be informed about the potential severe sequelae of animal bites and instructed to seek immediate medical advice, although bite wounds are minor or initial symptoms might be lacking. As proposed in the literature, 


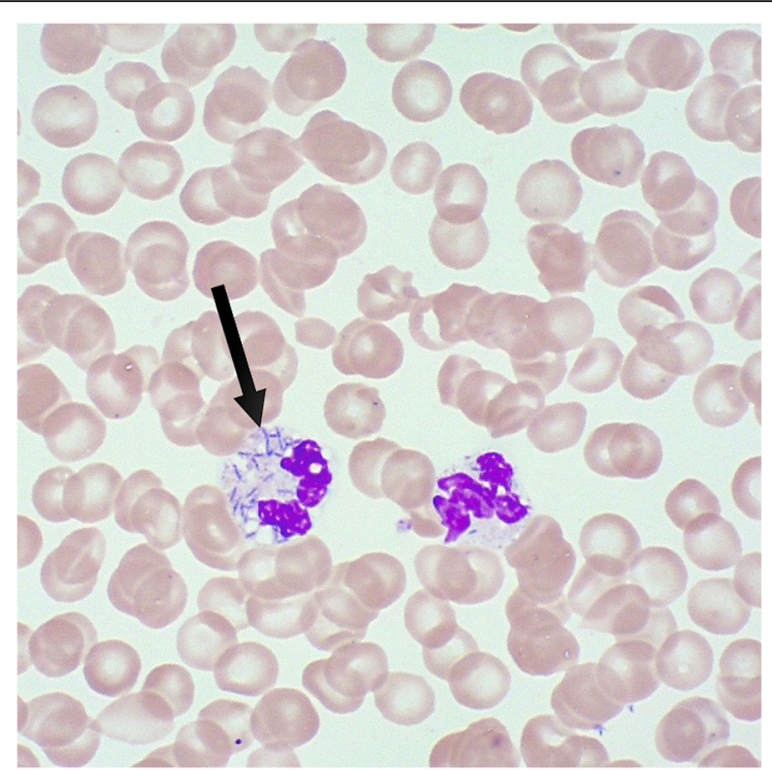

Fig. 2 Peripheral blood smear with May-Grünwald-Giemsa stain. Polymorphonuclear leukocyte with intracellular rod-shaped bacteria (black arrow $\longrightarrow$ ); image kindly provided by Health Center Fricktal, Rheinfelden, Switzerland)

physicians must initiate a pre-emptive antibiotic treatment in any wounds inflicted by cats and dogs in asplenic patients and should strongly consider pre-emptive treatment in other forms of immunosuppression (e.g., alcoholism) also [26, 28]. However, if ARCN is a new pathophysiologic entity associated with C.canimorsus infections or a result of the symptomatic DIC cannot be obtained from a single case.

\section{Abbreviations}

C. canimorsus: Capnocytophaga canimorsus; CT: Computed tomography: ARCN: Acute renal cortical necrosis; DIC: Disseminated intravascular coagulation; MALDI-TOF: Matrix-assisted laser desorption/ionization time-offlight mass spectrometry; MIC: Minimal inhibitory concentration; DF2: Dysgonic fermenter-2; Capnocytophaga spp: Capnocytophaga species

\section{Acknowledgments}

The authors are very grateful for the patient's willingness to present her extraordinary case to the medical world.

\section{Authors' contributions}

SAA obtained informed consent from the patient, collected all presented clinical data, and was responsible for the manuscript's writing and review process. KKS, CN, RS, MW, SSZ, AE, AH, and MS all participated in the manuscript's writing and review process. AH and MS have contributed equally. The author(s) read and approved the final manuscript.

\section{Funding}

No funding has been received for this publication.

\section{Availability of data and materials}

Not applicable.

\section{Ethics approval and consent to participate}

As this publication concerns single patient data in the form of a case report, ethics approval by the institutional review board was not required. Consent to participate has been obtained from the patient by SAA.

\section{Consent for publication}

Written informed consent was obtained from the patient for publication of this case report and any accompanying images. A copy of the written consent is available for review by the Editor of this journal.

\section{Competing interests}

RS received research grants from the Swiss National Foundation (No 320030_169379), the Research Fund of the University Basel, the Scientific Society Basel, the Gottfried Julia Bangerter-Rhyner Foundation, and UCBpharma. He received personal grants from UCB-pharma and holds stocks from Alcon, Novartis, Roche, and Johnson \& Johnson. The remaining authors have disclosed that they do not have any potential conflicts of interest.

\section{Author details}

${ }^{1}$ Intensive Care Medicine, University Hospital Basel, Basel, Switzerland.

${ }^{2}$ Division of Bacteriology and Mycology, University Hospital Basel, Basel, Switzerland. ${ }^{3}$ Applied Microbiology Research, Department of Biomedicine, University of Basel, Basel, Switzerland. ${ }^{4}$ Department of Clinical Research, University of Basel, Basel, Switzerland. ${ }^{5}$ Division of Infectious Diseases and Hospital Epidemiology, University Hospital Basel, Basel, Switzerland.

Received: 15 December 2020 Accepted: 12 February 2021 Published online: 27 February 2021

\section{References}

1. Poukkanen $M$, Vaara ST, Pettilä $V$, et al. Acute kidney injury in patients with severe sepsis in Finnish intensive care units. Acta Anaesthesiol Scand. 2013; 57(7):863-72.

2. Angus DC, Linde-Zwirble WT, Lidicker J, Clermont G, Carcillo J, Pinsky MR. Epidemiology of severe sepsis in the United States: analysis of incidence, outcome, and associated costs of care. Crit Care Med. 2001;29(7):1303-10.

3. Bagshaw SM, Uchino S, Bellomo R, et al. Septic acute kidney injury in critically ill patients: clinical characteristics and outcomes. Clin J Am Soc Nephrol. 2007;2(3):431-9.

4. Kawashima A, Sandler CM, Ernst RD, Tamm EP, Goldman SM, Fishman EK. CT evaluation of renovascular disease. Radiographics. 2000;20(5):1321-40.

5. Shiekh $Y$, llyas M. Reverse rim sign: acute renal cortical necrosis. Abdom Radiol (NY). 2018;43(12):3507-8.

6. Jordan J, Low R, Jeffrey RB Jr. CT findings in acute renal cortical necrosis. J Comput Assist Tomogr. 1990;14(1):155-6.

7. Brenner DJ, Hollis DG, Fanning GR, Weaver RE. Capnocytophaga canimorsus sp. nov. (formerly CDC group DF-2), a cause of septicemia following dog 
bite, and C. cynodegmi sp. nov., a cause of localized wound infection following dog bite. J Clin Microbiol. 1989;27(2):231-5.

8. Butler T, Weaver RE, Ramani TK, et al. Unidentified gram-negative rod infection. A new disease of man. Ann Intern Med. 1977;86(1):1-5.

9. Suzuki M, Kimura M, Imaoka K, Yamada A. Prevalence of Capnocytophaga canimorsus and Capnocytophaga cynodegmi in dogs and cats determined by using a newly established species-specific PCR. Vet Microbiol. 2010; 144(1-2):172-6.

10. Hess E, Renzi F, Karhunen P, et al. Capnocytophaga canimorsus capsular Serovar and disease severity, Helsinki Hospital District, Finland, 2000-2017. Emerg Infect Dis. 2018;24(12):2195-201.

11. Wilson JP, Kafetz K, Fink D. Lick of death: Capnocytophaga canimorsus is an important cause of sepsis in the elderly. BMJ Case Rep. 2016;2016: bcr2016215450. https://doi.org/10.1136/bcr-2016-215450. PMID: 27364692; PMCID: PMC4932406.

12. Butler T. Capnocytophaga canimorsus: an emerging cause of sepsis, meningitis, and post-splenectomy infection after dog bites. Eur J Clin Microbiol Infect Dis. 2015;34(7):1271-80.

13. Mader N, Luhrs F, Langenbeck M, Herget-Rosenthal S. Capnocytophaga canimorsus - a potent pathogen in immunocompetent humans systematic review and retrospective observational study of case reports. Infect Dis (Lond). 2020;52(2):65-74.

14. Barry I, Sieunarine K, Bond R. Ruptured mycotic common iliac aneurysm due to Capnocytophaga canimorsus, acquired from dog saliva: a case report. Int J Surg Case Rep. 2021;78:12-5.

15. Ashley PA, Moreno DA, Yamashita SK. Capnocytophaga canimorsus Aortitis in an Immunocompetent host. Hawaii J Health Soc Welf. 2020;79(11):324-5.

16. Edlukudige Keshava V, Bhavsar HV, Ghionni N, Baba RH, McNamee W. Overwhelming Sepsis due to Capnocytophaga canimorsus in an Immunocompetent individual: a rare case study. Cureus. 2020;12(9):e10177.

17. Terashima S, Hayakawa K, Saito F, et al. Hemophagocytic syndrome with severe sepsis caused by Capnocytophaga canimorsus. Am J Emerg Med. 2020;38(7):1540.e1545-8.

18. Bering J, Hartmann C, Asbury K, Vikram HR. Unexpected pathogen presenting with purulent meningitis. BMJ Case Rep. 2020;13(3):e231825.

19. Klein C, Mahé A, Goussot R, et al. Multiple erythema annulare centrifugum associated with knee monoarthritis revealing Capnocytophagacanimorsus infection. Ann Dermatol Venereol. 2020:147(5):373-6.

20. Squire $G$, Hetherington $S$. First reported case of lead-related infective endocarditis secondary to Capnocytophaga canimorsus: 'Dog Scratch' endocarditis. BMJ Case Rep. 2020;13(2):e233783.

21. Tani N, Nakamura K, Sumida K, Suzuki M, Imaoka K, Shimono N. An Immunocompetent case of Capnocytophaga canimorsus infection complicated by secondary thrombotic Microangiopathy and disseminated intravascular coagulation. Intern Med. 2019;58(23):3479-82.

22. Papadaki TG, el Moussaoui R, van Ketel RJ, Verbraak FD, Tan HS. Capnocytophaga canimorsus endogenous endophthalmitis in an immunocompetent host. Br J Ophthalmol. 2008;92(11):1566-7.

23. Nelson MJ, Westfal RE. Case report: vertebral osteomyelitis/discitis as a complication of Capnocytophaga canimorsus bacteremia. J Emerg Med. 2008:35(3):269-71.

24. Ehrbar HU, Gubler J, Harbarth S, Hirschel B. Capnocytophaga canimorsus sepsis complicated by myocardial infarction in two patients with normal coronary arteries. Clin Infect Dis. 1996;23(2):335-6.

25. Levey AS, Stevens LA, Schmid CH, Zhang YL, Castro AF 3rd, Feldman HI, Kusek JW, Eggers P, Van Lente F, Greene T, Coresh J. CKD-EPI (Chronic Kidney Disease Epidemiology Collaboration). A new equation to estimate glomerular filtration rate. Ann Intern Med. 2009;150(9):604-12. https://doi. org/10.7326/0003-4819-150-9-200905050-00006. Erratum in: Ann Intern Med. 2011 Sep 20;155(6):408. PMID: 19414839; PMCID: PMC2763564

26. Stevens DL, Bisno AL, Chambers HF, et al. Practice guidelines for the diagnosis and management of skin and soft tissue infections: 2014 update by the infectious diseases society of America. Clin Infect Dis. 2014;59(2):147-59

27. Zangenah S, Andersson AF, Özenci V, Bergman P. Genomic analysis reveals the presence of a class $D$ beta-lactamase with broad substrate specificity in animal bite associated Capnocytophaga species. Eur J Clin Microbiol Infect Dis. 2017;36(4):657-62.

28. Ellis R, Ellis C. Dog and cat bites. Am Fam Physician. 2014;90(4):239-43.

\section{Publisher's Note}

Springer Nature remains neutral with regard to jurisdictional claims in published maps and institutional affiliations.

\section{Ready to submit your research? Choose BMC and benefit from:}

- fast, convenient online submission

- thorough peer review by experienced researchers in your field

- rapid publication on acceptance

- support for research data, including large and complex data types

- gold Open Access which fosters wider collaboration and increased citations

- maximum visibility for your research: over $100 \mathrm{M}$ website views per year

At BMC, research is always in progress.

Learn more biomedcentral.com/submissions 